JAAKFE UNTAN

(Jurnal Audit dan Akuntansi Fakultas Ekonomi Universitas Tanjungpura)

Vol. 10 No. 1, Juni 2021

ISSN-P: (2252-7486), ISSN-E: (2746-6140)

https://jurnal.untan.ac.id/index.php/jaakfe

\title{
ETIKA PROFESI, PENGALAMAN, PENGETAHUAN, DAN AKUNTABILITAS AUDITOR BERPENGARUH TERHADAP KUALITAS AUDIT
}

\author{
Hairul Anam ${ }^{1) *}$, Wilma $^{2)}$, Hendika $S L^{3)}$ \\ ${ }^{1}$ Universitas Balikpapan, Indonesia \\ ${ }^{2}$ Universitas Balikpapan, Indonesia \\ ${ }^{3}$ Sekolah Tinggi Ilmu Ekonomi Balikpapan, Indonesia \\ E-mail: ${ }^{1) * h a i r u l @ u n i b a-b p n . a c . i d},{ }^{3)}$ hendika@ stiebalikpapan.ac.id
}

\begin{abstract}
This study aims to determine the effect of professional ethics, experience, knowledge, and auditor accountability on audit quality. The population in this study is the Inspectorate Office of the City of Balikpapan, with a sample of 30 people. The sampling technique in this study was purposive sampling method. Hypothesis testing in this research is multiple linear regression analysis method. The results showed that professional ethics and accountability had an effect on audit quality, while experience and knowledge had no effect on audit quality.
\end{abstract}

Keywords: Ethics of Profession; Experience; Knowledge; Accountability and Quality of the Audit.

Article History: Received:17-02-2021 Revised:04-06-2021 Accepted:08-06-2021 
Vol. 10, No. 1 (Juni 2021)

Hairul Anam, Wilma, Hendika SL

DOI: http://dx.doi.org/10.26418/jaakfe.v10i1.45046

Hal 1-9

\section{PENDAHULUAN}

Dimasa sekarang ini pemerintah dituntut untuk mewujudkan penyelenggaraan pemerintah yang efektif, efisien, akuntabel dan transparan yang bersih dan bebas dari praktik korupsi, kolusi dan nepotisme. Di perlukannya standar audit yang baik untuk memberikan keyakinan kepada laporan keuangan agar mencapai audit yang berkualitas. Pengelolaan keuangan pemerintah yang baik harus didukung auditor sektor publik yang berkualitas, jika kualitas audit sektor publik rendah kemungkinan memberikan kelonggaran terhadap lembaga pemerintah melakukan penyimpangan penggunaan dana. Selain itu juga mengakibatkan risiko tuntutan hukum (legitimasi) terhadap aparatur pemerintah yang melaksanakannya. (Susilawati \& Atmawinata, 2015)

Fenomena saat ini dikota Balikpapan adalah kasus audit Laporan Hasil Pemeriksaan (LHP) oleh Badan Pemeriksa Keuangan (BPK) RI atas Laporan Keuangan Pemerintah Kota (Pemkot) Balikpapan menunjukkan ada 26 penerima hibah organisasi kemasyarakatan belum sampaikan Laporan Pertanggung Jawaban (LPJ). Hasil audit itu berdasarkan LHP Laporan Keuangan Pemkot Balikpapan bernomor 14.A/LHP/XIX.SMD/V/2018 tertanggal 28 mei 2018. Tercantum bahwa total dana penerima hibah (dari 26 ormas) yang belum sampaikan LPJ adalah sekitar Rp 3,1 Milliar. Dalam audit BPK itu juga menjelaskan bahwa berdasarkan penjelasan dari salah satu anggota TAPD, proses pemberian hibah belum sepenuhnya sesuai dengan Peraturan Walikota. Hal yang tak sepenuhnya sesuai dengan Perwakil itu yakni ditemukan dalam pelaksanaanya untuk pencairan Belanja Hibah Tahun Anggaran 2017, tidak semua penerima hibah mengajukan proposal. Adanya hal yang tidak sesuai antara proses pengajuan dan Perwali Balikpapan itu disebutkan dalam LHP BPK mengakibatkan akuntabilitas dan transparansi pemberian hibah tahun 2017 belum sebelumnya terpenuhi (BPKAD, 2019).

Disimpulkan bahwa di temukannya kasus penyalahgunaan dana oleh BPK, mengisyaratkan bahwa pengawasan internal yang dilakukan oleh Pemerintah Kota Balikapapan dirasakan masih dikatakan belum optimal dalam mengawasi dan mencengah penyimpangan pengelolaan keuangan pemerintah daerah yang dilakukan pejabat-pejabat pemerintah. Sehingga dalam hal ini tingkat keahlian dan profesionalisme aparat pemerintah dalam bidang pengawasan harus ditingkatkan.

Guna menunjang profesionalismenya sebagai audit internal yang bekerja di inspektorat pemerintah, untuk meningkatkan kualitas yang belum optimal dalam melaksanakan tugasnya auditor harus mengetahui faktor-faktor apa saja yang dapat mempengaruhi kualitas audit. Faktor-faktor tersebut antara lain seperti etika profesi, pengalaman, pengetahuan dan akuntabilitas auditor. Menjujung tinggi aturan etika profesi dalam menjalankan tugas pemerikasaan sebagai auditor, merupakan salah satu faktor yang dapat mempengaruhi kualitas audit. Didalam profesi akuntan publik, nilai-nilai atau norma-norma yang dijadikan sebagai pedoman adalah tugas prefesionalnya. auditor harus mempunyai pengalaman kerja agar semakin terampil melakukan pekerjaan dan semakin sempurna pula berpikir dan sikap dalam bertindak untuk mencapai tujuan. Auditor yang tidak berpengalaman akan melakukan atribusi kesalahan lebih besar sehingga dapat memengaruhi kualitas audit.

Pengetahuan juga dapat memengaruhi kualitas audit, pengetahuan auditor adalah hal yang sangat penting dalam meningkatkan kualitas audit, terlebih pengetahuan dibidang akuntansi 
Vol. 10, No. 1 (Juni 2021)

Hairul Anam, Wilma, Hendika SL

DOI: http://dx.doi.org/10.26418/jaakfe.v10i1.45046

Hal 1-9

dan auditing. Untuk itu auditor harus selalu meningkatkan pengetahuan dan keahlian profesinya pada tingkat yang diperlukan untuk memastikan bahwa instansi tempat ia bekerja dapat menerima manfaat dari layanan profesinya berdasrkan pengembangan praktik, ketentuan dan teknik-teknik yang terbaru.

Akuntabilitas individu dalam melakukan suatu pekerjaan menentukan bagaimana sebuah informasi diproses. Hasil dari informasi yang diproses tersebut akan mempengaruhi respon, keputusan ataupun tindakan yang akan diambil. Prinsip integritas mengaruskan auditor untuk memiliki kepribadian yang dilandasi oleh unsur kejujuran, keberanian, bijaksana dan bertanggung jawab untuk membangun kepercayaan guna memberi dasar dalam mengambil suatu keputusan yang dapat diandalkan.

Tujuan dari penelitian ini adalah untuk memeroleh bukti empiris pengaruh etika profesi terhadap kualitas audit Kantor Inspektorat Kota Balikpapan, untuk memeroleh bukti empiris pengaruh pengalaman auditor terhadap kualitas audit di Kantor Inspektorat Kota Balikpapan, untuk memeroleh bukti empiris pengaruh pengetahuan auditor terhadap kualitas audit di Kantor Inspektorat Kota Balikpapan dan untuk memeroleh bukti empiris pengaruh akuntabilitas auditor terhadap kualitas audit di Kantor Inspektorat Kota Balikpapan.

Kualitas audit merupakan peluang auditor kemungkinan menemukan kemudian melaporkan mengenai pelanggaran suatu sistem akuntansi kliennya. Dalam melakukan audit, auditor harus memiliki independensi sehingga dapat memberikan opini atau kesimpulan sesuai dengan fakta yang terjadi tanpa ada pengaruh dari pihak berkepentingan. Audit yang berkualitas adalah ketika dalam melakukan proses audit sesuai dangan standar yang telah ditetapkandan auditor dapat mendeteksi kekeliruan atas penyajian laporan keuangan auditee sehingga dapat dilakukan evaluasi untuk meningkatkan kewajaran suatu laporan keuangan. (Sihombing \& Triyanto, 2019)

Penemuan yang diteliti oleh (Hasbullah, Sulindawati, \& Herawati, 2014; dan Trihapsari \& Anisykurlillah, 2016) menemukan bahwa etika berpengaruh terhadap kualitas audit. Adapun penjelasan oleh (Hasbullah et al., 2014; dan Trihapsari \& Anisykurlillah, 2016) adalah semakin tinggi sikap beretika dalam berprofesi sebagai seorang auditor yang ditunjukkan oleh seorang auditor dalam melaksanakan tugas audit, maka semakin tinggi pula kualitas audit yang dihasilkan. Etika berarti seperangkat nilai atau prinsip moral yang berfungsi sebagai panduan untuk berbuat, bertindak dan berprilaku.

H1: Etika Prpfesi berpengaruh terhadap kualitas audit.

Penemuan yang diteliti oleh (Ermayanti, 2017; dan Imron, Widyastuti, \& Amilin, 2017) menemukan bahwa pengalaman auditor berpengaruh signifikan terhadap kualitas audit. Adapun penjelasan (Ermayanti, 2017; dan Imron et al., 2017) adalah pengalaman yang baik dapat mengelola kualitas kerja secara optimal, dimana seorang auditor yang memiliki pengalaman yang tinggi dalam lingkungan kerja, cenderung dapat berinteraksi dengan banyak orang. Adanya pengaruh pengalaman auditor terhadap kualitas audit akan memberikan implikasi bahwa dapat menjaga kualitas audit secara komprehensif dengan adanya pengaturan tim dengan komposisi pengalaman yang dimiliki, membantu untuk pengambilan keputusan pimpinan untuk perbaikan kondisi proses bisnis dari auditee dan menjaga citra baik instansi atas nilai-nilai profesionalisme yang dimiliki oleh intansi. Berdasarkan hasil penelitian 
Vol. 10, No. 1 (Juni 2021)

Hairul Anam, Wilma, Hendika SL

DOI: http://dx.doi.org/10.26418/jaakfe.v10i1.45046

Hal 1-9

sebelumnya maka diajukan hipotesis sebagai berikut.

$\mathrm{H}_{2}$ : Pengalaman berpengaruh terhadap kualitas audit.

Penelitian oleh (Salsabila \& Prayudiawan, 2011; dan Wandita, Yuniarta, \& Nyoman, 2014) menemukan bahwa pengetahuan berpengaruh signifikan terhadap kualitas audit. Adapun penjelasan dari (Salsabila \& Prayudiawan, 2011; dan Wandita et al., 2014) adalah pengetahuan audit mempunyai kontribusi yang besar terhadap kualitas hasil kerja. Dengan adanya pengetahuan audit, auditor akan lebih hati-hati dalam menyeleksi setiap temuan audit dan dapat mendeteksi risiko-risiko yang akan terjadi dalam proses audit. Hasil yang diperoleh auditor akan mempengaruhi keputusan yang akan diambil. Jadi dapat dikatakan bahwa semakin tinggi pengetahuan seorang auditor maka semakin bermanfaat suatu keputusan yang akan diambil. Berdasarkan hasil penelitian sebelumnya maka diajukan hipotesis sebagai berikut.

$\mathrm{H}_{3}$ : Pengetahuan berpengaruh terhadap kualitas audit

Temuan yang diteliti oleh (Ermayanti, 2017; dan Salsabila \& Prayudiawan, 2011) membuktikan bahwa akuntabilitas berpengaruh signifikan terhadap kualitas audit. Adapun penjelasan oleh (Ermayanti, 2017; dan Salsabila \& Prayudiawan, 2011) adalah akuntabilitas menunjukkan bahwa tinggi nya motivasi auditor untuk mencurahkan segenap kemampuannya untuk menghasilkan pekerjaan yang berkualitas sesuai dengan kriteria yang telah ditetapkan. Hal ini mengindikasikan bahwa kualitas audit dapat dicapai apabila auditor dalam melaksanakan tugas audit selalu disertai dengan tanggungjawab, memiliki kecermatan yang tinggi dalam memeriksa laporan, mencurahkan usaha (daya pikir) dalam menyelesaikan tugas audit sertab selalu berpikir seoptimal mungkin dalam mengerjakan tugas audit. Berdasarkan penelitian sebelumnya maka diajukan hipotesis sebagai berikut.

$\mathrm{H}_{4}$ : Akuntabilitas berpengaruh terhadap kualitas audit.

Penelitian ini mengkaji pengaruh etika profesi, pengalaman, pengetahuan, dan akuntabilitas auditor terhadap kualitas audit di Kantor Inspektorat Kota Balikpapan.

\section{METODE PENELITIAN}

Penelitian ini dilakukan pada kantor Inspektorat yang berada di daerah Kota Balikpapan. Sampel pada penelitian ini adalah audit internal yang bekerja di kantor Inspektorat Kota Balikpapan. Metode penentuan sampel menggunakan metode purposive sampling sehingga diperoleh 30 audit internal sebagai sampel. Pengumpulan data menggunakan kuesioner. Teknik analisis data yang digunakan adalah analisis regresi linier berganda. Objek penelitian ini adalah kualitas audit di kantor Inspektorat Kota Balikpapan. Data yang diperoleh kemudian diolah. Hasil analisis dinyatakan dalam bentuk persamaan regresi linear berganda sebagi berikut :

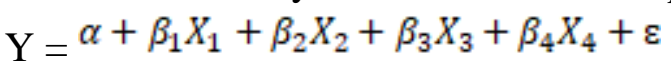

Keterangan:

$\mathrm{Y} \quad=$ Kualitas Audit

$\alpha \quad=$ Konstanta

$\beta_{1} \quad=$ Koefisien regresi dari kesadaran Etika Profesi $\left(X_{1}\right)$

$\beta_{2} \quad=$ Koefisien regresi dari kualitas Pengalaman $\left(X_{2}\right)$

$\beta_{3}=$ Koefisien regresi dari Pengetahuan $\left(X_{3}\right)$ 
Vol. 10, No. 1 (Juni 2021)

Hairul Anam, Wilma, Hendika SL

DOI: http://dx.doi.org/10.26418/jaakfe.v10i1.45046

Hal 1-9

$\beta_{4} \quad=$ Koefisien regresi dari Akuntabilitas $\left(X_{4}\right)$

$\mathrm{X}_{1} \quad=$ Etika Profesi

$\mathrm{X}_{2} \quad=$ Pengalaman

$\mathrm{X}_{3} \quad=$ Pengetahuan

$\mathrm{X}_{4} \quad=$ Akuntabilitas

$\varepsilon \quad=$ error

\section{HASIL DAN PEMBAHASAN}

\section{Hasil Analisis}

Analisis regresi digunakan untuk melihat pengaruh variabel bebas pada variabel terikat. Berdasarkan Tabel 3, dapat diringkas model persamaan regresi linear bergandanya sebagai berikut:

$$
Y=35,996+0,314 X_{1}-0,062 X_{2}+0,340 X_{3}-0,726 X_{4}+\varepsilon
$$

Nilai konstanta sebesar 35,996 menunjukkan bahwa variabel etika profesi, pengalaman, pengetahuan, akuntabilitas bernilai nol, maka nilai kualitas audit sebesar 35,966. Nilai koefisien regresi variabel etika profesi dalam model regresi ini sebesar 0,314. Nilai tersebut menunjukkan jika variabel independen lain yakni pengalaman, pengetahuan dan akuntabilitas bersifat kostan, maka setiap kenaikan 1 satuan nilai etika profesi akan diikuti dengan kenaikan kualitas audit sebesari 0,314. Koefisien regresi etika profesi bernilai positif artinya terjadi hubungan antara etika profesi dengan kualitas audit. Nilai koefisien regresi variabel pengalaman dalam model regresi ini sebesar -0,062. Nilai tersebut menunjukkan jika variabel independen lain yakni etika profesi, pengetahuan dan akuntabilitas nilainya tetap dan pengalaman mengalami kenaikan 1, maka kualitas audit akan mengalami penurunan sebesar 0,062. Koefisien regresi pengalaman bernilai negatif artinya terjadi hubungan negatif antara pengalaman dengan kualitas audit. Nilai koefisien regresi variabel pengetahuan dalam model regresi ini sebesar 0,340. Nilai tersebut menunjukkan jika variabel independen lain yakni etika profesi, pengalaman dan akuntabilitas bersifat konstan, maka setiap kenaikan 1 satuan nilai pengetahuan akan diikuti dengan kenaikan kualitas audit sebesar 0,340. Koefisien regresi pengetahuan bernilai positif artinya terjadi hubungan antara pengetahuan dengan kualitas audit. Nilai koefisien regresi variabel akuntabilitas dalam model regresi ini sebesar -0,726. Nilai tersebut menunjukkan jika variabel independen lain yakni etika profesi, pengalaman, dan pengetahuan nilainya tetap dan akuntabilitas mengalami kenaikan 1, maka kualitas audit akan mengalami penurunan sebesar 0,726. Koefisien regresi akuntabilitas bernilai negatif artinya terjadi hubungan negative antara akuntabilitas dengan kualitas audit.

Tabel 1. Hasil Analisis Regresi Linear Berganda

\begin{tabular}{lcllll}
\hline Model & \multicolumn{2}{l}{ Unstandardized Coefficients } & Standardized Coefficients & $\mathrm{t}$ & \multirow{2}{*}{ Sig. } \\
\cline { 2 - 4 } & B & Std. Error & Beta & & \\
\hline (Constant) & 35,996 & 2,765 & & 13,020 & 0,000 \\
X1 & 0,314 & 0,140 & 0,490 & 2,238 & 0,034 \\
X2 & $-0,062$ & 0,140 & $-0,136$ & $-0,444$ & 0,661 \\
X3 & 0,340 & 0,208 & 0,594 & 1,636 & 0,114
\end{tabular}


Vol. 10, No. 1 (Juni 2021)

Hairul Anam, Wilma, Hendika SL

DOI: http://dx.doi.org/10.26418/jaakfe.v10i1.45046

Hal 1-9

\begin{tabular}{|c|c|c|c|}
\hline$-0,726$ & 0,199 & $-1,121$ & $-3,644$ \\
\hline Adjusted $R$ Square & 0,304 & & \\
\hline Sig. F & 0,010 & & \\
\hline
\end{tabular}

Hasil analisis menunjukkan nilai Adjusted Rsquare sebesar 0,304. Ini berarti perubahan yang terjadi pada kualitas audit dapat dijelaskan oleh etika profesi, pengalaman, pengetahuan dan akuntabilitas sebesar 30,4 persen, sedangkan sisanya 69,6 persen dijelaskan oleh faktor lain yang tidak diuji dalam penelitian ini. Uji kelayakan model bertujuan untuk menguji apakah model yang digunakan dalam penelitian ini layak untuk digunakan atau tidak (Ghozali, 2018). Berdasarkan Tabel 3, nilai signifikansi $\mathrm{F}$ atau $p$-value sebesar 0,010 yang kurang dari nilai $\alpha=$ 0,05 . Hal ini menunjukkan bahwa regresi ini layak digunakan sebagai alat analisis untuk menguji pengaruh variabel bebas pada variabel terikat .

Nilai koefisien regresi untuk variabel etika profesi sebesar 0,314 dengan tingkat signifikansi sebesar $0,034<0,05$, maka $\mathrm{H} 1$ diterima. Hal ini mengindikasikan bahwa etika profesi berpengaruh positif dan siginifikan terhadap kualitas audit. Nilai koefisien regresi untuk variabel pengalaman sebesar -0,062 dengan tingkat signifikansi sebesar 0,661>0,05, maka $\mathrm{H} 2$ ditolak. Hal ini mengindikasikan bahwa pengalaman tidak berpengaruh positif terhadap kualitas audit. Nilai koefisien regresi untuk variabel pengetahuan sebesar 0, 340 dengan tingkat signifikansi sebesar $0,114>0,05$, maka $\mathrm{H} 3$ ditolak. Hal ini mengindikasikan bahwa pengetahuantidak berpengaruh positif terhadap kualitas audit. Nilai koefisien regresi untuk variabel akuntabilitas sebesar $-0,726$ dengan tingkat signifikansi sebesar $0,001<0,05$, maka $\mathrm{H} 4$ diterima. Hal ini mengindikasikan bahwa akuntabilitas berpengaruh positif dan siginifikan terhadap kualitas audit.

\section{Pembahasan}

Hasil pengujian analisis menyatakan nilai signifikansi sebesar 0,034 yang lebih kecil dari nilai koefisien $\alpha$ sebesar 0,05 berarti $\mathrm{H}_{1}$ diterima atau dapat diartikan etika profesi berpengaruh terhadap kualitas audit. Etika profesi dalam penelitian ini berpengaruh berarti searah dengan kualitas auditor atau dengan kata lain keahlian yang baik/tinggi dan menjujung tinggi kode etik profesi akan berpengaruh terhadap kualitas audit, demikian sebaliknya bila etika rendah/buruk maka kualitas audit akan rendah juga. Pengaruh signifikan menujukkan bahwa etika profesi mempunyai peranan yang sangat penting dalam menungkatkan kualitas audit. Pelaksanaan audit dengan mematuhi etika yang berlaku akan meningkatkan standar mutu pekerjaan sehingga hasil audit lebih berkualitas. Hasil penelitian ini sejalan dengan penelitian (Trihapsari \& Anisykurlillah, 2016) yang menyatakan semakin tinggi etika yang dimiliki oleh seorang auditor maka kualitas audit akan semakin tinggi, begitu pula sebaliknya jika etika yang dimiliki seorang auditor rendah maka kualitas yang dihasilkan akan rendah. Etika profesi merupakan karakteristik suatu profesi lain, yang berfungsi untuk mengatur tingkah laku para anggotanya. (Saputra \& Susanto, 2016) Moral dan etika memang mempunyai fungsi yang sama yaitu memberikan orientasi bagaimana sesorang bertindak yang baik dan menghindari perilaku tidak baik. Dalam setiap penugasan, auditor wajib mematuhi kode etik yang ditetapkan yang merupakan bagian yang tidak terpisah dari standar audit. 
Vol. 10, No. 1 (Juni 2021)

Hairul Anam, Wilma, Hendika SL

DOI: http://dx.doi.org/10.26418/jaakfe.v10i1.45046

Hal 1-9

Hasil pengujian analisis menyatakan nilai signifikansi sebesar 0,661 yang lebih besar dari nilai koefisien $\alpha$ sebesar 0,05 berarti $\mathrm{H}_{2}$ ditolak atau dapat diartikan pengalaman tidak berpengaruh terhadap kualitas audit. Pengalaman dalam penelitian ini tidak berpengaruh karena mungkin disebabkan oleh pertanyaan yang diajukan yaitu pertayaan semakin lama bekerja sebagai auditor, semakin dapat kesalahan yang dilakukan oleh obyek pemeriksaan dan pertanyaan banyaknya tugas yang diterima dapat mengacu auditor untuk menyelesaikan pekerjaan dengan cepat tanpa terjadi penumpukan tugas. hal ini dikarenakan sebagian auditor yang bekerja di Kantor Inspektorat Kota Balikpapan menjawab tidak setuju terhadap pertanyaan tersebut sehingga membuat variabel pengalaman tidak berpengaruh terhadap kualitas audit. Hasil penelitian ini sejalan dengan (Sihombing \& Triyanto, 2019) yang menyatakan bahwa pengalaman tidak berpengaruh terhadap kualitas audit. Auditor yang mempunyai banyak pengalaman dalam melakukan audit bukan menjadi suatu jaminan akan meningkatkan kualitas audit. Auditor membutuhkan proses pembelajaran untuk mengetahui suatu hal. Proses pembelajaran itulah yang dianggap sebagai pengalaman. (Badjuri, 2012) Pengalaman seorang auditor tidak menjadikan lama waktu kerja ataupun jumlah penugasan sebagai ukuran kualitasnya. Hal tersebut dikarenakan auditor yang sudah lama bekerja ataupun sudah banyak mendapat penugasan namun selama masa kerja atau penugasan tersebut selalu diberikan tugas yang sejenis (menoton) atau kompleksitas rendah maka tidak akan meningkatkan kualitas dari auditor tersebut. Dengan demikian sebaiknya seorang auditor dapat mengatur pembagian tugas audit yang lebih bervariasi dan memberikan pengalaman yang baru lagi bagi auditor.

Hasil pengujian analisis menyatakan nilai signifikansi sebesar 0,114 yang lebih besar dari nilai koefisien $\alpha$ sebesar 0,05 berarti $\mathrm{H}_{3}$ ditolak atau dapat diartikan pengetahuan tidak berpengaruh terhadap kualitas audit. Pengetahuan dalam penelitian ini tidak berpengaruh karena mungkin disebabkan oleh pendidikan auditor yang rata-rata hanya S1, hal ini berdampak dengan tingkat pengetahuan auditor, karena semakin tinggi tingkat pendidikan yang dimiliki oleh seorang auditor maka akan mempengaruhi pengetahuannya dalam melakukan tugas audit. Hasil penelitian ini sejalan dengan penelitian (Parasayu \& Rohman, 2014) yang menyatakan bahwa tidak selamnya pengetahuan auditor dapat meningkatkan kualitas audit. Pengetahuan auditor dapat dilihat dari pendidikan formalnya. Jika pendidikan formal seorang auditor dirasakan masih kurang maka auditor harus melakukan kursus atau melakukan pelatihan yang cukup memadai agar menunjang pekerjaanya. Jika pendidikan formal dapat dikembangkan dan diadakan pelatihan yang berkesinambungan maka dampak seorang auditor yang berpengetahuan ini akan terasa lebih signifikan terhadap kualitas pekerjaanya termasuk salah satunya adalah hasil auditnya.

(Sihombing \& Triyanto, 2019) yang menyatakan bahwa seringkali pengetahuan auditor dianggap dapat meningkatkan kompetensi auditor, namun dapat dilihat juga dari latar belakang pendidikan formal akuntansi. Pendidikan formal akuntansi dirasakan tidak lagi mengejar perkembangan isu-isu terbaru yang ada di dunia praktek sehingga para lulusannya bisa saja dianggap memiliki kompetensi yang baik dari segi pendidikan dan pengetahuannya, namun belum tentu mencerminkan kemampuan sesungguhnya saat berhadapan dengan kasus-kasus yang lebih kompleks didunia praktek. 
Vol. 10, No. 1 (Juni 2021)

Hairul Anam, Wilma, Hendika SL

DOI: http://dx.doi.org/10.26418/jaakfe.v10i1.45046

Hal 1-9

Hasil pengujian analisis menyatakan nilai signifikansi sebesar 0,001 yang lebih kecil dari nilai koefisien $\alpha$ sebesar 0,05 berarti $\mathrm{H}_{4}$ diterima atau dapat diartikan akuntabilitas berpengaruh terhadap kualitas audit. Akuntabilitas dalam penelitian ini berpengaruh berarti akuntabilitas sangat penting bagi auditor sebagai faktor yang mempengaruhi kualitas audit. Akuntabilitas bisa membuat instansi mempertahankan hal-hal yang positif mengenai kualitas audit yang dihasilkan, karena auditor bertanggungjawab atas pekerjaanya, melakukan audit dengan upaya yang kuat, menggunakan kekuatan pemikiran, memobilisasi seluruh energy dan pikiran dalam melaukan audit, sehingga mampu meningkatkan kualitas audit.

Hasil penelitain ini sejalan dengan penelitian (Salsabila \& Prayudiawan, 2011) yang menyatakan bahwa semakin besar akuntabilitas seorang auditor maka semakin tinggi kualitas hasil kerja yang dihasilkan. Kualitas dari hasil kerja auditor dapat dipengaruhi oleh rasa bertanggung jawab (akuntabilitas) sebagai bentuk dorongan psikologi yang membuat seseorang berusaha mempertanggung jawabkan semua tindakan dan keputusan yang diambil dalam lingkungannya. (Laksita \& Sukirno, 2019) Akuntabilitas sangat penting bagi auditor karena mampu meningkatkan kualitas audit. Akuntabilitas menunjukkan bahwa auditor dapat menyelesaikan audit dengan baik dan tepat waktu serta dapat mempertanggung jawab atas audit yang telahdilakukan

\section{SIMPULAN DAN SARAN}

Berdasarkan hasil penelitian yang telah dilakukan mengenai pengaruh etika profesi, pengalaman, pengetahuan, dan akuntabilitas auditor terhadap kualitas audit (studi empiris pada kantor inspektorat Kota Balikpapan), maka dapat ditarik kesimpulan sebagari berikut.

1. Etika profesi berpengaruh terhadap kualitas audit. Hal ini menunjukkan bahwa etika merupakan suatu perbuatan yang dimana menjadi landasan berindaknya seorang auditor. Semakin tinggi sikap beretika dalam berprofesi sebagai seorang auditor yang ditujukkan dalam melaksanakan tugas audit, maka dapat meningkatkan kualitas audit yang dihasilkan dan dapat memberikan kontribusi yang baik untuk menjalankan tugas audit.

2. Pengalaman tidak berpengaruh terhadap kualitas audit. Hal ini dikarenakan mungkin pengalaman yang dimiliki oleh auditor masih membutuhkan waktu untuk melakukan proses pembelajaran dalam melakukan audit. Pengalaman auditor tidak menjadikan lama waktu ataupun jumlah penugasan sebagai ukuran kualitasnya.

3. Pengetahuan tidak berpengaruh terhadap kualitas audit. Hal ini dikarenakan tidak selamanya pengetahuan menjadi faktor yang mempengaruhi kualitas audit. Dapat dilihat dari latar belakang pendidikan formal akuntansinya.

4. Akuntabilitas berpengaruh terhadap kualitas audit. Hal ini menunjukkan bahwa akuntabilitas penting untuk meningkatkan kualitas audit. Semakin tinggi akuntabilitas seorang auditor maka kualitas audit yang dihasilkan auditor dapat dipertangugungjawabkan sehingga laporan keuangan yang telah diaudit diharapkan lebih berkualitas sesuai dengan standar yang telah ditentukan.

Saran yang dapat disampaikan adalah Bagi para auditor diharapkan dapat mengendalikan faktor apa saja yang dapat mempengaruhi kualitas audit, contohnya seperti etika profesi, pengalaman, pengetahuan, dan akuntabilitas agar dapat menambah kualitas audit yang baik, 
Vol. 10, No. 1 (Juni 2021)

Hairul Anam, Wilma, Hendika SL

DOI: http://dx.doi.org/10.26418/jaakfe.v10i1.45046

Hal 1-9

serta dapat lebih ditingkatkan lagi kinerja atau pelatihan-pelatihan untuk dapat tersertifikasi dalam kualitas auditor. Bagi peneliti selanjutnya disarankan menggunakan sampel lebih banyak lagiatau objek penelitian dapat diperluas, menambahkan variabel yang diduga dapat mempengaruhi kualitas audit.

\section{DAFTAR PUSTAKA}

Badjuri, A. (2012). Analisis Faktor-Faktor Yang Berpengaruh Terhadap Kualitas Pemeriksaan Auditor Intern Kota Semarang. Prosiding Seminar Nasional Multi Disiplin Ilmu \& Call For Paper UnisBank, 423-434.

Ermayanti, D. (2017). Pengaruh Emotional Quotient, Pengalaman Auditor Dan Akuntabilitas Terhadap Kualitas Audit. Eksis, 12(2), 178-190. ISSN: 2549-6018

Ghozali, I. (2018). Aplikasi Analisis Multivariate dengan Program SPSS 25 Edisi 9. ISBN: 979704-015-1

Hasbullah, Sulindawati, N. L. G. E., \& Herawati, N. T. (2014). Pengaruh Keahlian Audit, Kompleksitas Tugas, Dan Etika Profesi Terhadap Kualitas Audit. E-Journal S1 Ak Universitas Pendidikan Ganesha, 2(1).

Imron, M. A., Widyastuti, T., \& Amilin. (2017). Pengaruh Pengetahuan Audit, Independensi Dan Audit Investigasi Pada Auditor Inspektorat Jenderal Kementerian Keuangan. Jurnal Ilmiah WIDYA Ekonomika, 1(3), 1-8. ISSN: 2337-6686

Laksita, A. D., \& Sukirno. (2019). Pengaruh Independensi, Akuntabilitas, dan Objektivitas Terhadap Kualitas Audit. Jurnal Nominal, 8(1).

Parasayu, A., \& Rohman, A. (2014). Analisis Faktor-Faktor Yang Mempengaruhi Kualitas Audit Internal ( Studi Persepsi Aparat Intern Pemerintah Kota Surakarta dan Kabupaten Boyolali ). Diponegoro Journal Of Accounting, 3(2), 1-10. ISSN: 2337-3806

Salsabila, A., \& Prayudiawan, H. (2011). Pengaruh Akuntabilitas, Pengetahuan, Audit, Dan Gender Terhadap Kualitas Hasil Kerja Auditor (Studi Empiris Pada Inspektorat Wilayah Provinsi DKI Jakarta). Jurnal Telaah \& Riset Akuntansi, 4(1), 155-175.

Saputra, A., \& Susanto, D. S. (2016). Kompensasi , Independensi , Profesionalisme dan Etika Profesi Internal Auditor terhadap Kualitas Audit di Inspektorat Jenderal Kementerian Ketenagakerjaan. Jurnal Riset Akuntansi Dan Perpajakan, 3(2), 21-32. ISSN: 2339-1545

Sihombing, Y. A., \& Triyanto, D. N. (2019). Pengaruh Independensi, Obyektivitas, Pengetahuan, Pengalaman Kerja, Integritas Terhadap Kualitas Audit (Studi Pada Inspektorat Provinsi Jawa Barat Tahun 2018). Jurnal Akuntansi, 9(2), 141-160. ISSN: 2303-0364

Susilawati, \& Atmawinata, M. R. (2015). Pengaruh Profesionalisme Dan Independensi Auditor Internal Terhadap Kualitas Audit: Studi Pada Inspektorat Propinsi Jawa Barat. Etikonomi, 13(2), 190-210. ISSN: 1412-8969

Trihapsari, D. A., \& Anisykurlillah, I. (2016). Pengaruh Etika, Independensi, Pengalaman Audit Dan Premature Sign Off Terhadap Kualitas Audit. Accounting Analysis Journal, 5(1), 1-7. ISSN: 2252-6765

Wandita, N. L. P. T. A., Yuniarta, G. A., \& Nyoman, A. S. D. (2014). Pengaruh Pengetahuan, Pengalaman Kerja Audit, dan Akuntabilitas Terhadap Kualitas Hasil Kerja Auditor Internal. E-Journal S1 Ak Universitas Pendidikan Ganesha, 2(1). Retrieved from https://ejournal.undiksha.ac.id 